\title{
The Future of Business and Business School Pedagogy Reconvergence
}

\author{
Adrian Teja \\ Prasetiya Mulya Business School \\ Cilandak Barat, Jakarta 12430, Indonesia \\ adrianteja@pmbs.ac.id
}

\begin{abstract}
Business world is constantly changing in a different way that the past had low predictive power to predict the future. In the last ten years, new business paradigms have gained the tractions. There are new business strategies to remove business constraints as much as possible, for rehumanization the consumer and to achieve multiple objectives simultaneously such as profit, social, and environment. The emergence of new business paradigms also means that industries competition landscapes are mutating and create a new industry that has completely different characteristics and a different success factor key. While business world is changing, business school pedagogy has relatively been the same in the last 30 years. The implications are $t h$ a $t$ business school become more and more irrelevant to business world and more big companies start to develop their corporate university to better address their own challenges. We address those issues by reviewing business school pedagogy philosophy. We find that business school pedagogy has drawbacks such as their time orientation is mostly based on the past of business successes and failures with a relatively stable environment if it is compared to today environment, and their heavy emphasis on a partial analysis and partial problem solvings, such as the case of segregation. To overcome this major drawbacks, we believe that business school pedagogy may be innovated by changing the time of orientation for the future of educators and students externship, whereas current and future business issues may be discussed and solved with a good collaboration with company's management.
\end{abstract}

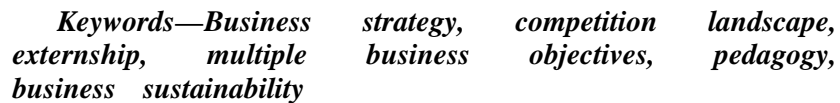

\section{INTRODUCTION}

Peoples have tendencies to perceived landscape as stable and immovable, while in fact landscape is constantly changing and that changing may or may not be repeated [1]. Business world is also constantly changing in a way that the predictive power of past events getting weaker each day, but business executives have mostly stick to the old ways in order to manage a business [2][3]. Business executives mostly rely on the same old tools to comprehend business world. The popular management tools, such as Porters 5 forces analysis and GE Matrix, are designed to be use in a relatively stable world and the business has little power to change the industry rule of the game or has a low malleability. Reliance on the same old tools over and over again systematically reduce the fitness between strategy and market competition requirement and their performance [4][5]. The examples of company casualties are
Nokia and Barnes \& Noble. Nokia the mobile phone maker was shutted down because of the competition from chinese companies phone maker for a low cost mobile phone and Apple and Samsung for premium mobile phone. Nokia was also unable to monetize their innovation, HERE - 3D mapping services, and they are being forced to sell HERE to German Automaker for USD 3 billion in 2015. Barnes and Noble late responded to compete other companies in different industries, such as Apple and Samsung, and in the trend it was possible to be bankrupt.

The emergence of UBER, AirBnB, Vocaloid, and many more, mark the day when new business paradigms start to replace the old business paradigms. The old business paradigm is grounded on theory of the firm that asserts that the firm raison d'etre is minimizing cost [6][7]. Within the scope of local economy, this old business paradigm is leading to business vertical integration, business horizontal diversification, and business unrelated diversification or conglomeration. Within the scope of global economy, this old business paradigm is leading to multinational firms that operates across countries to take an advantage of a comparative advantage and an absolute advantage among countries to achieve the economic scale in a global level [8].

While old business paradigms is still a dominant force in the business world, there are three new business paradigms that have gained tractions in the last ten year. The first business paradigm is a business effort to remove the business constraints as much as possible. For example UBER and AirBnB succeeded in removing constraints to assets the ownership and transforming their firms as a nexus of contracts [9]. Vocaloid succeeded to remove constraints for time availability. These new companies business models have enabled them to adjust their capacity more efficiently than their old business competitors, thereby posing a great threat to the old business sustainability.

The second business paradigm is business effort for rehumanization of their customers [10]. A business effort to minimize the cost has negative side effects that reduce customers' role only to their economic role. For example, companies only see their investors as financial resources, their employees are no different than machine, and their customers are seen as a source of revenue. The customers start getting tired to companies' dehumanization effort and switch their buying activities to companies that acknowledge them as human being. 
The third business paradigm is business needs to achieve several objectives simultaneously beyond the profits perse. Achieving more than one objective is more difficult but it is not impossible $[11,12,13]$. The third business paradigm triggered by global warming and the rising power of stakeholders. The society demand companies to be more actively involved in the cultivation of good society and the cultivation of a livable environment $[14,15]$.

The three new business paradigms imply that companies need to have the right strategy, the right governance structures, in finding and attracting valuable resources, such as business funding and talents, solving the society problems through providing good products and services, learning and continuously developing, and expanding business boundaries and scalling up business competencies without losing focus. This is where business school should step forward and actively contributes to companies needs through educating young talent to be a competent graduate that is also wise and care for the society and the environment. But more and more companies see business school losing its lustre. Business school graduates are seen as not competence enough to address the future of business challenges. Hence, companies, especially big companies, start to develop their own corporate university.

Considering this phenomena, the aim of this paper is to provide suggestions to reconverge the future of business school and business school pedagogy. We assess business school pedagogy and their weaknesses then we provide suggestions to make business school innovating their pedagogy to make themselves to remain relevant in addressing the future of business challenges.

\section{Business School Pedagogy}

Business school pedagogy can be understood through business school learning methods and business school learning environment. There are three categories of learning method, a. lecture based, b. problem based, and c. work based. Lecture based is performed in class where the faculty members explain concepts to students in brief and then discuss the concepts with students. Students usually already have the text books to help them learn and understand the basic concepts.

Lecture based learning have several drawbacks. The first drawback, lecture based learning focus to attain basic competencies. This basic competencies will be learned in every business school, hence mastering the basic competencies will not provide one business school graduates an edge in competition with graduates from other business schools. The second drawback, basic competencies have been relatively stable in the last thirty years . For example, we still define and calculate the time value of money exactly the same with our predecessor. But, it is more often than not, we feel confident when we use the latest edition text books. We feel business text books with the latest edition represent the most current and provide the most sophisticated tools to understand and manage the business. The third drawback, text book is usually authored by faculty member from developed countries. This text book has a little use in emerging countries because of the business environment, regulations, and infrastructure is relatively underdeveloped. The concepts from developed countries need to be adjusted several times in order to be relevant and valuable to be applied in the emerging countries. The forth drawback, faculty members usually give their student assignment to answer the problems at the end of chapter. In the era of a strong search engine and free information, what students do is searching for an answer, and they do not learn how to think and solve the problems. It becomes a habit for students to passively wait for questions and actively search for the answer from the internet. The last or fifth drawback is myopic view. Concepts are learned and applied partially not integratively. For example, when we define taxi industries boundaries, we thought taxi companies competitors are other taxi companies. But, the existence of UBER, Lyft, Sidecar, and Gojek has changed taxi industry boundaries considerably. Taxi industry competitors are (1) Gojek, a motorcycle taxi located in Indonesia, a major threat to taxi industries in the form of competition in the same market and competition for its driver, i.e. many taxi drivers choose to be Gojek drivers because of the flexible working time and a higher potential income, (2) Ford as a vehicle manufacturer has already developed vehicles that are compatible with driverless car that are compatible to be used with UBER, Lyft, and Sidecar apps, and (3) Google has also developed a driverless car.

Besides text books, faculty members also encourage their students to read academic journal. The drawbacks of academic journal is that each paper focuses not on narrow but deep analysis of particular business phenomena and different authors may have different hypothesis or pros and cons concerning a unique phenomenon. To be applied correctly, the concept from a paper needs several steps to be understood and modified. The fact that there is no unique theory for one unique business phenomena implies that students have to read a lot of paper to relatively understand the "true meaning" of business phenomena.

Problem based learning is performed using mini cases such as the end of a chapter problems and business case. We have already discussed end of chapter problems above hence we will focus our analysis to business case. Business case as a part of business school pedagogy originated from Harvard University's Law School in the late nineteenth centuries. Later in the early twentieth century, Harvard Business School started to adopt this method of learning. The purpose of business case is to expose students to the simplified world or hypothetical world to help them understand the problems within unstructured situations, develop solutions, and recommend actions. Then it turns out, business case as a part of business school pedagogy is a major success and imitated all over the world until now.

Based on the purposes, there are nine categories of business case [16]. There are iceberg cases, the predictive series of cases, living cases, multimedia cases, focused decision cases, unfocused decision cases, implementation cases, appraisal cases, and simple or complex cases. Iceberg cases refer to simple cases from a sample of situation. Predictive cases refer to cases that have relation with iceberg cases with the purpose of building diagnosis and recommendation skills. Multimedia cases refer to cases that try to mimic live situation using audio and visual 
simultaneously. Living cases refer to live cases that are being experienced by the executives. Focused decision cases refer to cases that have specific and clear objective with the purpose to develop technical expertise. Unfocused decision cases refer to cases that present the situations with the purpose to develop analytical skills to discover and define the problems and their possible solutions. Implementation cases refer to a case that is designed to build implementation skills of favored decision. Appraisal cases relatively the same as unfocused decision cases, but appraisal cases dig deeper to uncover assumptions, processes, and characteristics of the situations under investigation. Last but not least, simple or complex cases refer to the level of data analysis needed to solve the cases.

Business cases also have their limitations. First, case study is oriented to a popular event. The popular business case usually happens to large companies with large resources, large enough news and large data availability. A very small percentage of business case is built on normal business cases. While most of us will work in a small to medium company, learning how large companies manage their issues has a little value when applied to small and medium enterprises. Second, a case study is usually developed in a world where competition is relatively stable and companies have little power to alter the course of the industries. Third, a business case is usually built to solve or achieve one objective, i.e. target profit, target market share, etc., and relatively a small number of business case built to solve or achieve more than one objectives simultaneously, such as profit oriented, society oriented, and environment oriented. And fourth, the business case is mostly market oriented and has a very little emergence of its market-oriented nature.

To supplement the lecture based learning and problem based learning, business school also encourages their students, especially their fresh graduates, to work based on learning in the form of an internship or an apperentice program in real companies. Within the companies, students are expected to apply their newly gain of knowledge and concepts to solve problems that companies face. In reality, the number of companies that open their door for apperentice program are relatively limited and their work performed within the apperentice program seems limited to a low value added activity, such as clerical works.

Business school learning environment refers to whether the environment are built sufficiently for students to learn and apply the business concepts as an individual and as a team. Business school has already provided enough literatures and infrastructure for collaborative learning. Hence, we will move forward and analyze the learning environment concerning class activities and the diversity of management. From my observations, time in class activities are mostly spent by learning basic competencies and discussions about the concepts and their applications in business world as remainder.

Current business complexities and uncertainties ensure that no one is smart enough to compherend complexities and deal with uncertainties. So, the answer lies in a group or a team learning working together to solve the problems and achieve multiple objectives simultaneously.
Business school usually assumes that giving problem based on learning in the form of business cases to be solved by students as a group or team will automatically develop students' capability to work as a team, reach consensus and communication skills. It is true that a group learning may be built using business cases, but is it sufficient? We believe that it is not the case, since the dynamic of a team is difficult to build, in the form of diversity and inclusivity, and also it is very difficult to comprehend, especially for faculty members that do not specialize in dynamic groups. Hence, we have a strong conviction that the diversity and inclusivity in a team work to solve business case is not fully developed and utilized. If diversity and inclusivity is not properly addressed, our graduates will be at odds when they have to deal with the market for diversity and inclusivity.

\section{Redesigning Business School Pedagogy}

The future of business needs talents that are able to see the big picture while anchored to the reality and Talents that are able to achieve multiple objectives optimally, and talents that have executions capabilities. To provide graduates that cater to the future of business needs, business schools have to reinvent their pedagogy concerning a. changing time orientation from orientation to the past to orientation to the future, $b$. finding new ways to make new concepts or finding new ways to make old concepts relevant again, and c. actively linking a business school to business world. Reinvention is important because business school pedagogy is relatively the same if it is compared to thirty years ago.

Changing time orientation from orientation to the past to the orientation into the future implies that companies have to achieve several objectives simultaneously. Companies should not only focus on power and profit, but business that is also wise and care for society and environment. We believe that it is business school duties and opportunities to be a role model, by leading good examples when they educate their students. Eventhough, there is the word "business" in a business school, a business school is not a "pure" company. A business school is just like other higher educations or institutions that have functions larger than merely a profit machine. If a business school only manages to gain profit, how can we persuade our students to be the agent of change that build business that have simultaneously positive contribution to profit, social, and environment.

Business schools are also facing competitions from companies in different industries. For example: Coursera and Khan Academy that provide free educations. Competition pressures usually force a business school to minimize its cost. One popular way to minimize the cost is to maximize the ratio of faculty members related to the number of students.

Business schools that make an excessive effort for efficiency maximization may have negative side effects, such as exhausted faculty members and faculty member quality being unable to catch up with the progress of the business world. Faculty members are exhausted not because of more research or more contribution to the society but of giving too many lectures. 
Since minimizing cost has its limit, it is imperative to shift attention to other issues. I believe business schools need to find a new source of incomes, such as consultation fees and research grants. This new source of income may solve two problems simultaneously, the issues concerning faculty members and the issues of making business schools become relevant again to the business world.

There are two issues concerning faculty members. The first issue is insufficient quantity of faculty members and the second issue is the insufficient quality of faculty members. Understanding the first issue is relatively straight forward, most competence people choose to work in business world, not in academic world because the salary and remuneration package is higher. It is normal and there is nothing wrong with that. Only selected people choose to ignore salary and remuneration package from the business world to work in academic world. The solution for the issue is business school should provide better salary and remuneration package to attract talents from the business world to strengthen the academic world, and then retain them in the academic world.

When the issue of faculty member quantity has already been partially solved, we may proceed to tackle the issue of insufficient quality of faculty member. Optimal faculty member relative to number of students enable faculty members to have more value added activity on top of giving lectures. There are several value added activities that can be performed by faculty members such as publications in academic journal, publication in mass media, such in newspaper, seminar, conferences, including their research impacts to the business world.

Business school and its faculty members also should be supported to have a good quality relationship with the business world. One type of good quality relationship with business is externship[17][18][19]. Externship is usually performed by faculty members by spending two weeks or more to work within the company and being actively involved in framing the problems and designing solutions for the problems that are being faced by company. Working within company, the faculty members may improve their competence because they are able to combine their explicit knowledge, i.e. theories, and tacit knowledge, i.e. execution capability [20].

Good relationship between business schools and faculty members and companies have several positive impacts. The first positive impact, business school may have a new source of incomes when they contribute to companies, societies, and environment. The second positive impact, the faculty members, after combining explicit knowledge and tacit knowledge, may find new ways to make old concepts to be relevant again. The third positive impact, good relationships also will improve the number of companies that participate and improve the quality internship program because companies experience positive economic impacts from the internships programs. [21].

\section{CONCLUSIONS}

The future of business lies in new young talents. It is a business school duty and opportunity to educate and to be the role model for the young talents. Business school pedagogy is relatively the same as that of business school pedagogy thirty years ago. Business school pedagogy in the past was built upon business world that was relatively stable and business had a little power to alter the rule of the game. Today and in the future, business school pedagogy needs to be reinvented to address the issues faced by the business world, which are more unpredictable, more unstable, and more demanding. Industries boundaries are constantly changing and business constraints are constantly removed. While at the same time, the society and the environment need a business that is not only focused on power and profit, but a business that is also wise and cares for the society and the environment.

Business schools need to change their time orientations from orientation to the past to orientation to the future and finding new concepts or finding new ways to make old concepts become relevant again. This change needs additional costs, hence a business school will need new source of income in the form of consultation fees and research grants beside tuition fees. New source of income in the form of consultation fees may be obtained from externship programs. Externship may improve faculty member competencies by combining explicit knowledge and tacit knowledge and at the same provide positive contribution to the companies. Research grants may enable faculty member to develop new concepts to address the future of business challenges.

\section{References}

[1] J M Mayo. "Temporary landscapes". Journal of Architectural and Planning Research, vol. 26, no. 2, Summer, 2009, pp. 124-135.

[2] M Reeves, C Love and P. Tillmanns. "Your strategy needs a strategy". Harvard Business Review, September, 2012.

[3] M Ruef. "Assessing organizational fitness on a dynamic landscape: An empirical test of the relative inertia thesis". Strategic Management Journal, vol. 18, no. 11,Dec., 1997, pp. 837-853.

[4] A Bird and S Beechler. "Links between business strategy and human resources management strategy in US Based Japanese Subsidiaries: An empirical investigation”. Journal of International Business Studies, vol. 26, no.1, $1^{\text {st }}$ Qtr., 1995, pp.23-46.

[5] E M Olson, S F Slater and G T M Hult. "The performance implications of fit among business strategy, marketing organization structure, and strategic behavior". Journal of Marketing, vol. 69, no. 3, Jul, 2005, pp. 49-65.

[6] R H Coase. "The Nature of The Firm". Economica, vol. 4, no. 16, 1937, pp. 386-405.

[7] O E Williamson. Markets and hierarchies: Analysis and antitrust implications. New York: The Free Press, 1975, ISBN 978-0029353608.

[8] P Krugman. "The increasing returns revolution in trade and geography". American Economic Review, vol. 99, no. 3, 2009, pp. 561-571.

[9] M C Jensen and W H Meckling. "Theory of the firm: Managerial behavior, agency costs and ownership structure". Journal of Financial Economics, vol. 3, no. 4, 1976, pp. 305-360.

[10] L Rediehs. From dehumanization to rehumanization. Carnegie Council fro Ethics in International Affairs, 2014.

[11] C W Sealey, Jr. "Financial planning with multiple objectives". Financial Management, vol. 7, no. 4, Winter, 1978, pp. 17-23.

[12] S M Lee and A J Lerro. "Capital budgeting for multiple objectives". Financial Management, vol. 3, no. 1, Spring, 1974, pp.58-66.

[13] S S Bell and G S Carpenter. "Optimal multiple-objective marketing strategies”. Marketing Letters, vol. 3, no. 4, Oct, 1992, pp. 383-393.

[14] G Serafeim. "The role of corporation in society: An alternative view and opportunities for future research". Working paper, Harvard Business School, 2014. 
[15] M Devlin. "The future of business". The RSA Journal, vo. 156, no.5543, 2010, pp.40-41.

[16] M Calkins. "Casuistry and the business case method". Business Ethics Quarterly, vol. 11, no. 2, 2001, pp. 237-259.

[17] P Foncault. "Viewpoint: Linking schools to business". The Clearing House, vol. 75, no. 3, Jan-Feb, 2002, pp. 163-165.

[18] V D Luft. School-to-Work: “A business and industry program for educators". The Clearing House, vol. 70, no. 6, Jul-Aug, 1997, pp. 325327.
[19] V D Luft and K L Vidoni. "Educator externships: How classroom teachers can acquire business and industry experience". The Clearing House, vol. 74, no. 2, Nov-Dec, 2000, pp. 81-83.

[20] J A Raelin. "A model of work-based learning”. Organization Science, vol. 8, no. 6, Nov-Dec, 1997, pp. 563-578.

[21] T Bailey, K Hughes and T Barr. "Achieving scale and quality in schoolto-work internships: Findings from two employer surveys". Educational Evaluation and Policy Analysis, vol. 22, no. 1, Spring, 2000, pp. 41-64. 